\title{
Islam and Human Rights: Theoretical And Practical Framework In Indonesia
}

\author{
Masykuri Abdillah \\ Syarif Hidayatullah \\ State Islamic University Jakarta, Indonesia \\ masykuriabdillah@uinjkt.ac.id
}

\begin{abstract}
This paper explains the compatibility of Islam and Human Rights, although in fact Muslim countries are generally considered as being less respective and less protective of human rights. As one the Muslim countries, Indonesia has committed to protect human rights since the beginning of its independence, as showed by its 1945 Constitution. The concept of Indonesian human rights is adjusted to the Indonesian own philosophy and culture based on Pancasila. In the reform era (1998-present), the state commitment to human rights protection is stronger than in the previous periods. Nevertheless, there are problems or challenges in human rights protection caused by several factors, classified into structural and cultural factors. The government and the parliament have made efforts to overcome the problems and challenges by making regulations that are compatible with human rights and strengthening law enforcement to avoid human rights violation. Besides, political parties and civil society organizations also take part in educating people and countering any action that violates human rights.
\end{abstract}

Keywords-Human Rights; Darûriyyat (Human Necessities:, Freedom; Human Rights Violation; Human Rights Protection;

\section{INTRODUCTION}

Human rights and democracy become important issues in the life of nation and state as well as international relations. Human rights and democracy are two things interrelated to each other. Democracy cannot exist without the existence of human rights, and human rights generally cannot exist without democracy. Nevertheless, there are debates, especially between the liberal state and the socialist state as well as the Muslim states. The universal concept of human rights, which originated from the Western culture and civilization, was then spelled out by many countries, particularly with the aim of adjusting the concept of human rights appropriately to their regional or local culture and their national interests.

There, thus, exist several regional declarations of human rights, such as the Convention for the Protection of Human Rights and Fundamental Freedoms in 1950 supported by the
European countries united in the Council of Europe; and the African Charter of Human and People's Rights in 1981. Muslim countries also made efforts to adjust the concept of human rights to the context of Islam, so that in 1990 the state members of the Organization of Islamic Conference (OIC) issued the Cairo Declaration of Human Rights in Islam. On November 18, 2012, ASEAN member countries signed the ASEAN Human Rights Declaration in Pnom Penh, Cambodia. The Declaration refers to the Universal Declaration of Human Rights affirming its implementation to give regional and national contexts of each country into account.

Although since the beginning, Islam has recognized the existence of human rights, in fact, Muslim countries are generally considered as being less respective and less protective of human rights, including the existence of diversity. Unfortunately, many observers connect such a condition to Islamic precepts are considered as being incompatible with universal human rights. As one the Muslim countries, Indonesia has been committed to protect human rights since the beginning of its independence, as showed by its 1945 Constitution. In the reform era (1998-present), the commitment is stronger than that in the previous periods. Nevertheless, there are sometimes debates on the concept of human rights, especially concerning the necessity of adjustment of the rights into Indonesian own culture. There are also problems and challenges in protection and enforcement of human rights. This paper will describe and analyze human rights in Islam as well as their concept and practices in Indonesia, including their problems, especially those influenced by religious factors.

\section{ISLAM AND HUMAN RIGHTS}

Since the beginning, Islam has recognized the substance of human rights, formulated by the classical ulama as al-umûr aldarûriyyât (necessities) and al-umûr al-hâjiyyât (needs) which must be catered for and protected in human life. The al-umûr al-darûriyyât consist of hifz al-dîn (protection of religion), hifz al-nafs (protection of life) hifz al-'aql (protection of reason), hifz al-mâl (protection of property) and hifz al-nasab (protection of descent). The term "huqûq al-insân" as the translation of human rights and its formulation has been popular in Muslim societies only since the end of World War 
II. This is because religious teachings generally emphasize obligations rather than rights. Rights will be achieved if the individual fulfills his obligations and responsibilities. In fact, all governments in Muslim countries, as well as almost all ulama and Muslim intellectuals, support the term of human rights. The Cairo Declaration of Human Rights in Islam in 1990 agreed by the OIC members shows the support. [1]

Islam recognizes that humankind consists of various social groups, be that is based on race, nation or religion. As stipulated in the Quran 49 (al-Hujurât):13, men are created into nations and tribes in order to know and to respect one another. Meanwhile, as stated in the Quran 17 (al-Isra'): 70, men are endowed with human dignity (karamah) and completed by faculty for a reason, which other creatures do not have. This produces the variety and diversity of opinions, behaviors, and inclinations among the people, which among other things take the form of various religions or religious schools/sects as well as social and political groups. Because the diversity is a sunnah Allah (natural law) and recognized in the Quran, it is an obligation for Muslim governments and communities to respect and protect such diversity by the existence of tolerance.

Freedom of religion is one of the human rights stipulated in the Universal Declaration of Human Rights (article 18), which implies freedom to have a religion or to have no religion as well as to convert to other religion. Islam recognizes this right as a manifestation of individual's free will. There are some Quranic verses that introduce these rights among other things: Qur'ân 2 (al-Baqarah): 256: "Let there be no compulsion in religion. Truth stands out clear from error"; Qur'ân 88 (alGhâshiyah): 21-22: "Therefore do thou give admonition, for thou art one to admonish. Thou art, not one to manage (men's) affairs"; Qur'ân 50 (al-Dhâriyât): 45: "We know best why they say, and thou art, not one to compel them by force. So admonish with Qur'ân such as fear My Warning", and Qur'ân 10 (Yûnus): 99: "If it had been thy Lord's Will, they would all have believed, all who are on earth! Wilt you then compel mankind, against their will, to believe."

This means that Islam supports religious pluralism understood as religious diversity that gives freedom to various religious followers to exist and to express their belief in public life. Islam does not recognize religious pluralism understood as promoting similarity among religions as well as the relativity of truth of religious doctrines [2]. Since the beginning, Muslims and Muslim rules guaranteed freedom of belief and worship for non-Muslims. It is true that in the early periods of Islam, Muslim rules conquered non-Muslim territories, but this was the military and political aspects only and not a religious one because non-Muslims were free to continue their religious practices. Although they were called dhimmî (protected non-Muslims) obliged to pay jizyah (polltax), this was considered as being very tolerant at that time because non-Muslim rulers or groups generally did not give such freedom and protection.

In the context of freedom of religion, there is problem or debate concerning a Muslim who converts to another religion (apostate, murtad). According to classical fiqh (Islamic jurisprudence), the apostate is condemned to capital punishment, based on the Hadîth: "Whoever changes his religion, kill him". Today certain governments and many ulamas continue to keep this stipulation, although it is today considered as being incompatible with human rights. Because the stipulation of apostasy (riddah) in the classical fiqh is incompatible with the universal declaration of human rights, some ulamas reinterpret this stipulation. In the perspective of Islamic legal theory (usûl al-fiqh), the reinterpretation of this Hadith is justified, because it does not indicate absolute text (nass qat $\left.{ }^{`} \hat{\imath}\right)$ (Shaltut: 1966). Obviously, Allah does not judge the apostate in this world, namely by capital punishment. He will judge him in the hereafter as stated by Qur'ân al-Baqarah: 217 , "And if any of you turn back from their faith and die in unbelief, their works will bear no fruit in this life and in the Hereafter; they will be companions of the fire and will abide therein". Besides, it is also based on Qur'ân 4 (al-Nisâ'): 137, "Those who believe, then reject Faith, then believe (again) and (again) reject Faith, and go on increasing in Unbelief, Allah will not forgive them nor guide them on the Way".(Fazlur, 1986: 16)

One of the reasons for reinterpreting the above Hadith is because of the historical setting in which the Prophet spoke. The basic relations among the social groups at that time were dominated by conflict and war. If someone left one group, he would join another group that was an enemy of the first group, and he could be an informant or spy about the first group's secrets. Thus, his action is considered as subversive action. Conversely, where relations among various groups (nations) are of peace, there is no strong reason to condemn the apostate (murtad) by capital punishment. This means that Islam basically supports a principle that the relationship of the individual with his fellow man is based on mutual respect, not mutual negation. This means that someone has right to change his religion as long as this is based on his own will.

Besides, there also exist certain Quranic verses that are textually not in line with the human rights, namely concerning the position of non-Muslims as dhimmîs. The classical fiqh considered them as the second class of citizen and obliged to pay jizyah (poll-tax) as stipulated in Quran 9 (al-Tawbah): 29: "... until they pay the jizyah with willing submission, and feel themselves subdued". This verse should be reinterpreted by a new concept that gives the equal status of non-Muslims in a Muslim society or state because the circumstances have already changed. In the early period of Islam, the principle of human relations was based on conflict, and a Muslim who lived in the non-Muslim territory was treated as the secondclass citizen. Conversely, today, the principle of human relations is based on peace mentioned above, and non-Muslim societies or states recognized the existence of Muslims by protecting their rights based on peaceful relationship. The contemporary ulama are generally inclined to the opinion that the basic relationship between Muslims and non-Muslims is one of peace. This is based on Qur'ân 8 (al-Anfal): 61: "But if the enemies incline towards peace, do thou (also) incline towards peace, and trust in Allah". The word "islâm" itself means submission, welfare, safety, and peace. This means that according to Islam, the relationship between Muslims and non-Muslim is practically conducted on the principle of reciprocal relations. 


\section{HUMAN RIGHTS IN INDONESIA}

As one the Muslim countries, Indonesia has been committed to respect and to protect human rights since the beginning of independence, as stipulated in the 1945 Constitution. The emergence of "reform era" following the fall of authoritarian Soeharto's government in 1998 has been marked as the starting point of transition to substantive democracy in Indonesia, which also means greater commitment for human rights protection. The commitment takes the form of legislation of Human Rights Act of 1999, followed by the legislation of Human Rights Court Act of 2000. Then the second amendment of the 1945 Constitution in 2000 includes the provisions of human rights in more detail. In line with this, the government has empowered the National Commission for Human Rights (Komisi Nasional Hak Asasi Manusia, Komnas HAM) established in 1993.[5]

In 2005, the House of Representatives (Dewan Perwakilan Rakyat, DPR) ratified the International Covenant on Economic, Social and Cultural Rights (ICESCR) by Ratification Act of 11/2005 and the International Covenant on Civil and Political Rights (ICCPR) by Ratification Act of $12 / 2005$. This was considered as an important historical event because in the New Order era, many intellectual and human rights activists suggested the government and the DPR to ratify these two Covenants to give more protection of human rights, but they always rejected the suggestion. This means that Indonesia is one of the countries in the world that has the complete instruments of human rights. Consequently, the government is obliged to the implementation of the instruments by making policies and measures to recognize, to respect, to protect and to fulfill human rights. In line with this, the government and the DPR are obliged to reform state regulations that are incompatible with human rights.

The governments in the reform era (1998-present) has recognized, respected, and protected human rights and made them a vision of all sectors of national development. Human rights enforcement becomes a government program stipulated in the Rencana Pembangunan Jangka Panjang Nasional (RPJPN, Long Term Planning of National Development). Unlike the New Order government that restricted freedom, the government in the reform era strongly supports freedom as a precondition of respecting human rights. The government guarantees freedom of expression, including in the forms of criticism, oppositions, demonstrations, and protests directed to the government. It also guarantees political freedom, including the establishment of religious party forbidden in the New Order era. During this era, the government has conducted free elections, in which the citizens could freely express their choices of political parties and candidates according to their own aspirations.

Yet there are debates on the implementation of human rights protection, especially concerning universalism and particularism of the concept of human rights. The universal concepts of human rights originated from Western culture and civilization which are secular in nature. It is possible to understand and implement human rights in the context of a certain society whose philosophical and cultural backgrounds are not the same as the Western cultural background. As we know, Indonesia, which is based on Pancasila, is neither a secular nor a religious state. In term of political institutions, Indonesia is secular, but in term of state philosophy, it is not secular because it recognizes the existence of religion in the life of society and state. Hence, it is possible and even necessary to take particular values or rights into consideration in order to adjust the implementation of human rights to Indonesian own philosophy and culture. The 1999 Human Rights Act defines human rights as "a set of rights attached to the nature and existence of human beings as the creatures of God Almighty and is a gift that must be respected and protected by the state, law, government and every person for the honor and protection of human dignity."

The main thing that is somewhat different between the concept of human rights in Indonesia and that in the West is the notion of freedom and its border. The liberal group argues that the limitation is unjustifiable, [6] but the 1945 Constitution recognizes the limitation, as stipulated in the article $28 \mathrm{~J}$ of the 1945 Constitution. The limitation is aimed merely to ensure recognition and respect for rights and freedoms of others and to fulfill just demand by taking morality, religious values, security and public order into consideration. Such a limitation is also justified by the International Covenant on Civil and Political Rights (ICCRP), as stipulated in article 18 (3). Moreover, such limitation is not contrary to democracy, because democracy is making a balance between freedom and order based on the rule of law. This means that there are borders or limitation of expressing a freedom that is compatible with Indonesian society; and this is a kind of adjustment of universal human rights to particular conditions.

\section{Problems and Challenges}

The serious debates on the limitation of freedom are only that related to religious freedom, defined as a notion that promotes individual or collective freedom to express their religion and belief in teaching and practice, either in private or public life. It also generally recognizes the freedom to change religion or not to follow any religion. In a country that recognizes official religions, the government should protect the existence of other religions or belief systems, although this does not necessitate giving facilities to them. Religious freedom is stipulated in the 1945 Constitution, namely article 28 E (1): "Every person shall be free to choose and to practice the religion of his/her choice". It is also stipulated in article 28 E (3): "Every person shall have the right to the freedom to believe his/her faith"..., and article 29 (2): "The State guarantees all persons the freedom of worship, each according to his/her own religion or belief".

Hence, the implementation of religious freedom in Indonesia is not fully the same as that of in the Western, Middle East or other Asian countries. There are certain differences between secular, religious and semi-secular or semi-religious countries. This means that although religious freedom is a universal principle, its implementation can be variously adjusted to national interest or local culture of each country. In Indonesia, which is based on Pancasila, there is no 
fully separation of state and religion, and that the state's responsibility toward religion is not only limited to protection of religious freedom but also to provide services to the followers of the religion, including protection of citizen's rights to defend the purity of their religious teachings and practices.[7] The latter occurs only if there is fundamental deviation of religious principles introduced by certain religious groups and leads to social disharmony or conflict.

In the context of interfaith relations, generally, there is also no longer problem of freedom of religion in term of differences of religions. Every religious adherent has the same rights and obligation as a citizen, including the right to live and has safety from violence, as stipulated in the article $28 \mathrm{~A}$ of the 1945 Constitution: "Every person shall have the right to live and to defend his/her life and existence". Interfaith conflicts or tensions are generally not purely caused by religious factors, but rather by economic, political, and social factors, which then connected to religion to gain greater support or solidarity from fellow-adherents because religion in Indonesia is still becoming a sensitive issue. Part of the expression of religious freedom is constructing a house of worship and conducting religious dissemination or propaganda. There are sometimes interfaith tensions that partly lead to violence caused mostly by improper construction of houses of worship and active religious proselytizing that are not in line with the existing regulations.[8]

There are problems and challenges in human rights protection caused by several factors, classified into structural and cultural ones. Principally, there is no problem in term of substantive law or instruments of human rights, because several regulations have been repealed or amended, such as Act No 11/PNPS/1963 on Eradication of Subversive Activities. The Constitutional Court and the Supreme Court have an authority to judicial review of the regulations, and these two Courts have properly performed their authority toward regulations brought to them for judicial review. There are certain problems of human rights protection concerning the existing weaknesses of law enforcement. In several cases, the police violated human rights, although the government has no longer adopted "security approach" as done by the New Order government, especially in the cases dealing with brutal demonstrators and protesters.

Another problem of human rights protection is the existing legal culture that is not fully conducive to human rights protection, especially legal awareness of many Indonesian people that is still low. Respecting human rights requires the existence of tolerance among various groups of society, although this is not light for a country that consists of a multicultural society like Indonesia. In the reform era, which supports substantive democracy and freedom, radicalism has emerged as an expression of freedom; and conversely, the level of tolerance has tended to decline. The emergence of radicalism and extremism, especially those based on religious motivation within the Islamic community, becomes a serious challenge or threat of human rights protection in Indonesia. They have taken advantage of the existing freedom to express and propagate their radical and extremist ideology.
The government has made serious efforts to combat and restrict religious radicalism and terrorism through security approach and cultural approach. In 2010, the government established the National Agency for Combating Terrorism (BNPT) to strengthen the government's efforts in combating terrorism, with the involvement of religious leaders and scholars in the implementation of its programs, especially in the form of de-radicalization and counter-radicalism. Since the last 15 years, the religious leaders have also conducted efforts to prevent and restrict religious radicalism. They spread the correct understanding of religious teachings (especially Islam), which promotes peace and harmony in accordance with its mission as "rahmat li al-alamin" (blessing for the universe). They also condemned violence and terror and consider them as desecrating Islam and violating human rights.

\section{CONCLUSION}

It can be concluded that since the beginning, Islam has recognized the existence of human rights, although in fact Muslim countries are generally considered as being less respective and less protective of human rights. As one the Muslim countries, Indonesia has committed to protecting human rights since the beginning of its independence, as showed by its 1945 Constitution. In the reform era (1998present), the commitment is stronger than in the past as shown by the legislation of Human Rights Act of 1999 and ratification of International Covenant on Economic, Social and Cultural Rights as well as International Covenant on Civil and Political Rights in 2005. The government has recognized, respected and protected human rights. The government also guarantees freedom of expression, including in the forms of criticism, oppositions, demonstrations and protests directed to the government. Nevertheless, there are problems or challenges in human rights protection caused by several factors, classified into structural and cultural factors.

Therefore, efforts to overcome the problems and challenges should be conducted by the government, the DPR and political parties as well as civil society organizations, especially religious organizations. Legal reform should be conducted, especially concerning regulations that are incompatible with human rights, while the government should make human rights protection as a vision of all sectors of national development. In accordance with this, the government should strengthen law enforcement to avoid human rights violation committed either by security forces or by a group of the citizen. Besides, the government and religious organizations should make serious efforts to restrict and to combat any form of radicalism through both security and theological approaches. In line with this, the government should improve legal awareness of the citizens, especially through civic education inside and outside of school. 


\section{REFERENCES}

[1] Although Muhammad 'Imarah wrotes a book, Al-Islam wa Huqûq alInsân, Darûrât Lâ Huqûq (Islam and Human Rights, Necessities, Not Rights), he certainly does not reject human rights. He wants to explain that Islam stipulates more obligations and responsibilities, not merely rights. See Muhammad 'Imarah, Al-Islâm wa Huqûq al-Insân: Darûrât lâ Huqûq, (Damascos: Dar al-Salam, 2004), p. 13.

[2] As stated in the Quran 3 (Âlu 'Imrân): 85: "And whoever seek a religion other than Islam, it will never be accepted of him", Islam is the only true religion, while recognizing the truth of previous religions practiced without corruption and heresy, as stipulated in the Quran 2 (al-Baqarah): 62. Some liberal Muslim intellectuals support religious pluralism in the second meaning, while criticizing truth claim as one of dominant factors that lead to religious conflict.

[3] Mahmud Shaltut, Al-Islâm 'Aqîdah wa Sharî’ah, (Kairo: Dar al-Qalam, 1966), p. 289

[4] Cf. Fazlur Rahman, "Non-Muslim Minority on an Islamic State", Journal Institute of Muslim Minority Affairs, Vol. 7 No. 1, 1986, p. 16.

[5] The Commission has the task: (1) to develop conditions conducive to the implementation of human rights in accordance with Pancasila, the 1945 Constitution, and the Universal Declaration of Human Rights, (2) to improve protection and enforcement of human rights for the development of personality Indonesian people and their ability to participate in various areas of life.

[6] Concerning regulation of religious life requested to maintain and strengthen religious harmony, certain minority groups argue that establishing houses of worship and religious proselytizing constitute expression of freedom of religion which is a non-derogable, yet the state and the majority groups argue that freedom of religion is a nonderogable right, but its expression to the public is a derogable right.

[7] Even a number of Western countries also do not fully separate church and state; and conversely, give religion official status in the state stipulated in the constitution. The article 2 of the 2012 Norwegian Constitution, for example, states that "The basis of our values remains our Christian and humanist inheritance", the article 4 states: "The King at all times professes the Evangelical-Lutheran religion". This means that the official inclusion of religion into the state is not only typical of Muslim countries, but also practiced by a number of Western countries.

[8] Minister of Religious Affairs issued Ministerial Decree number 70/1978 on Ethics of Religious Propaganda. Then the government issued the Joint Regulation of 9/2006 and of 8/2006 between Minster of Religious Affairs and Minster of Home Affairs to revise the Joint Decree of 1969 , especially concerning construction of houses of worship.>>>>Alawiyah, Tuti. "Religious non-Governmental Organizations and Philanthropy in Indonesia," in Indonesian Journal of Islam and Muslim Societies, Vol. 3 , No. 2, December 2013: 203-221, 216-218. 